\title{
全国地形分類図による表層地盤特性のデータベース化， および，面的な早期地震動推定への適用
}

\author{
工学院大学* 久保智弘・久田嘉章・柴山明寛 \\ 防災科学技術研究所** 大井昌弘・石田瑞穂・藤 原 広行 \\ ジオ・システム・ソリューション*** 中山圭子
}

\section{Development of Digital Maps of Site Amplification Factors in Japan, and Their Applications to Early Strong Motion Estimations}

\author{
Tomohiro Kubo, Yoshiaki Hisada and Akihiro Shibayama \\ Kogakuin University, Dept. of Architecture \\ Nishi-Shinjuku 1-24-2, Tokyo 163-8677, Japan \\ Masahiro OoI, Mizuho IsHida and Hiroyuki FujIwara \\ National Research Institute for Earth Science and Disaster Prevention \\ Tennodai 3-1, Tsukuba, Ibaraki 305-0006, Japan
}

Keiko NAKAYAMA

Geo System Solution, Inc.

Hikarigaoka 6-1-1-214, Nerima, Tokyo 179-0072, Japan

(Received April 2, 2002; Accepted February 7, 2003)

\begin{abstract}
We developed digital maps of the geomorphological land classifications and the site amplification factors in Japan, and applied them to strong motion estimations immediately after earthquakes. For making the maps, we first digitized the geomorphological land classification maps of Japan (1: 200,000 or $1: 100,000$ scale) and constructed $500 \mathrm{~m}$ mesh data. Then, we made up the maps of site amplification factors using the empirical relation by Midorikawa and Matsuoka (1995). We evaluated their accuracies by comparing the estimated strong ground motions with the records of K-Net for recent earthquakes in the Kanto area. We estimated the strong motions using the site amplification factors and the two methods: the attenuation relation (Si and Midorikawa, 1999), and an interpolation method using the records. We found that the second method gave more reliable results than the first method, because the first method strongly depended on accuracies of the source and path effects. However, since we may not be able to obtain quickly strong motion records near highly damaged areas, it would be efficient to evaluate the strong motions using the first method immediately after an earthquake, then to replace them by the second method after getting the records. Finally, we compared the site amplification factors using the following two methods. The first is based on the average of shear wave velocities from the free surface to the $30 \mathrm{~m}$ depths using boring data. The second is the above-mentioned method based on the land classifications. The comparisons showed that the first method was more accurate and reliable. Therefore, it is necessary to replace the digital maps of the site amplifications by those using the first method, when we obtain boring data.
\end{abstract}

Key words: Geomorphological land classification, Digital map, Site amplification factor, Early strong motion estimation, Attenuation relation, K-Net 


\section{§1.はじめに}

1995 年阪神・淡路大震災を契機に，多くの自治体で 地震被害想定が行われた[例えば，損害保険料率算定会 (1998)]。また全国を対象とした地震被害想定の支援 ッールが開発され，公開されている[例えば，内閣府 (1999), 座間・細川 (1996), 座間・他 (2000)]。地震被害 想定で基本となる地震動推定には，まず表層地盤のデー タベース化と増幅特性の評価が重要となる，現在，全国 を網羅する表層地盤のデータベースとして国土数值情報 [日本地図センター(1992)］があり，上記の支援ッール でも使用されている。しかしながら，国土数值情報の メッシュ単位は $1 \mathrm{~km}$ の基準地域メッシュ（第 3 次地域 区画）であり，地盤増幅特性の評価む地形分類による経 験的手法 [松岡・翠川 (1994)］を用いているため, 精度 や解像度に改善の余地がある。一方，自治体に上る地震

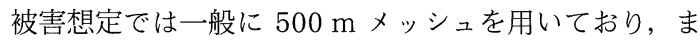
たボーリングデータやPS 検層デー夕を用いた地盤増幅 特性を考慮しているため, より解像度と精度に優れてい ると考えられる [例えば，損害保険料率算定会 (1998)]. しかしながら地盤増幅の評価は，各自治体ごとに独自の 手法を用いて実施されており，広い地域を対象とした地 震動推定を行う場合, 想定結果に隣県同士で不整合など あ起こりうる.

一方, 阪神・淡路大震災以降, 早期の地震情報の収集 や被害予測を行うため，国・自治体や企業などで大規模 な地震計ネットワークが構築され，それぞれ独自のシス テムが起動するようになった[例えば，翠川 (1996, 2002)]. 例えば気象庁では全国で約 600 点の震度計 ネットワークを整備し, 震度情報を地震発生から約 2 分 後にはテレビなどで一般に公表している [例えば，横田 (2002)]，一方，内閣府では緊急災害対策本部等の応急対 策実施を支援するための地震防災情報システム (DIS) の 整備を進めている [例えば，桐山 (2000)]. DIS には気象 庁の震度情報加ら被害推定を行う EES (地震被害早期推 計システム) が含まれているが，推定手法には国土数值 情報による地震被害想定支援マニュアル[内閣府

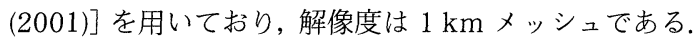
一方, 自治体や企業でも独自の高密度な地震計ネット ワークを用いた早期地震被害推定システムを開発してい る. 例えば, 横浜市では約 $2 \mathrm{~km}$ 間隔で市内 150 力所に 強震計を配置しており，これを利用した早期地震防災シ ステム (READY) を開発した [例えば， Midorikawa et al. (2000)]。また東京ガスの SUPREME［清水・他 (2002)] では SI センサーを首都圈の約 3700 力所という 高密度で設置し，それぞれ早期地震防災システムを構築 している。.また，海外でも同様な試みが行われており，
例えば米国・南カルフォルニアでは California Institute of Technology (Caltech), U.S. Geological Survey (USGS), および California Division of Mines and Geology (CDMG) が共同して強震観測ネットワーク (TriNet) を運営している。 そしてこのシステムを用いた 即時的な地表加速度・速度・震度マップ (Shake Map) を Web 上で公開している [Wald et al. (1998)].

ところで，独立行政法人・防災科学技術研究所では, 高感度地震観測網 (Hi-net), 広帯域地震観測網 (FREESIA network，2002 年 4 月より F-net），強震観測網 (K-NET, KiK-net) を整備してきており，それを活用し たリアルタイム地震情報伝達システム (ROSE; Realtime Operation System for Earthquake) を構築して いる [大井 (2001), 石田・大井 (2002)].このシステムで は地震発生後, 数分以内に震源決定を行い, 距離減衰式 を用いた面的な地震動推定を行う。さらに強震観測記録 が得られ次第，推定地震動の精度を向上させ，結果を Web上にて公開している[防災科学技術研究所 (2002)].

本研究の目的は, ROSE での地震動推定の基礎となる 全国の地盤増幅特性マップを整備し，さらに距離減衰式 および強震記録を元にした地震動推定の精度のチェック

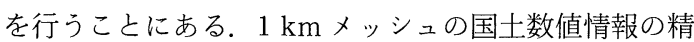
度を改善する試みとして, 若松・他 (2002) は土地分類 基本調査の地形分類図（縮尺 5 万分の 1）を基に，地形 分類デー夕を作成中である．それに対して本研究では全 国土地分類図の地形分類図（縮尺 20 万分の 1 ，または

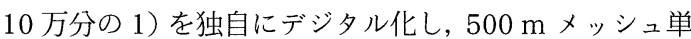
位で地形分類図のデータベースを作成する．次に内閣府 の地震被害想定支援ッールをもとに，全国を網羅する $500 \mathrm{~m}$ メッシュの地盤増幅度マップを構築する.さらに 関東平野を対象として，地震被害想定支援マニュアルを もとに，距離減衰式と K-NET による強震動記録を用い た面的な地震動推定を行い，実際に観測された強震記録 の結果との比較からの精度の検討を行う。その際, 地盤 増幅特性の評価は地形分類と標高デー夕をもとにした手 法 [松岡・翠川 (1994), 翠川・松岡 (1995)] 之, PS 検層 デー夕をあとにした手法 [Midorikawa et al. (1994)] の 比較検討も行う. 最後に, 面的に推定した震度と気象庁 による震度との比較を行い，推定結果の検討も行う.

\section{§2．表層地盤特性のデータベース化}

全国を対象に面的な地震動推定を行うため，本研究で は地形分類図をもとに $500 \mathrm{~m} メ ッ シ ュ$ 単位での表層地 盤特性のデータベースを作成する。デー夕の作成は県別 の土地分類図の地形分類図 [例えば，国土庁土地局国土 
Table 1. Geomorphological land classifications and the corresponding coefficients for the site amplification factors (Midorikawa and Matsuoka, 1995).

\begin{tabular}{|c|c|c|c|c|c|}
\hline \multirow{2}{*}{ classifications } & \multirow{2}{*}{$\begin{array}{c}\text { classification } \\
\text { code }\end{array}$} & \multicolumn{2}{|c|}{ coefficient } & \multicolumn{2}{c|}{ the extent of hight } \\
\cline { 3 - 6 } & 1 & $\boldsymbol{a}$ & $\boldsymbol{b}$ & lower & upper \\
\hline Mountain & 2.64 & 0 & - & - \\
\hline Plateau & 2 & 2 & 0.28 & $10 \mathrm{~m}$ & $400 \mathrm{~m}$ \\
\hline Alluvial fan & 3 & 1.83 & 0.36 & $15 \mathrm{~m}$ & $200 \mathrm{~m}$ \\
\hline Natural levee & 4 & 1.94 & 0.32 & $5 \mathrm{~m}$ & $30 \mathrm{~m}$ \\
\hline Sand bar & 5 & 2.29 & 0 & - & - \\
\hline Valley plain & 6 & 2.07 & 0.15 & $10 \mathrm{~m}$ & $500 \mathrm{~m}$ \\
\hline Delta & 7 & 2.34 & 0 & - & - \\
\hline Reclaimed land & 8 & 2.23 & 0 & - & - \\
\hline River,others & 0 & - & - & - & - \\
\hline
\end{tabular}

調査課 (1976)] を使用する.これは $1 / 10$ 万または $1 / 20$ 万の地図であり, 分解能は $400 \mathrm{~m}$ から $1 \mathrm{~km}$ とされて いる. したがって，地域によっては $500 \mathrm{~m}$ メッシュの 解像度が無い場合ああると考えられるが，下に示す東京 都の例のように十分に高い精度を示す地域むある.さら

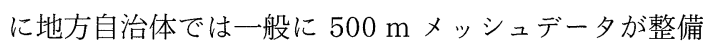
されており，今後それらのデータを活用することも考慮 し，ここでは全国を一律に $500 \mathrm{~m}$ メッシュでデー夕を 作成する. 同時に国土数值情報の $1 \mathrm{~km} メ ッ シ ュ$ 単位の 地形分類図との比較を行い, 解像度を検討する.

まず, 本研究で用いる地震被害想定支援マニュアルに よる速度の増幅度マップの作成法を説明する，増幅度は (1) 式による経験式 [Midorikawa et al. (1994)] を用い る.

$$
\log R=1.83-0.66 \log A V S_{30}
$$

ここで $R$ は工学的基盤に対する表層地盤による速度の 増幅度, $A V S_{30}$ は地表から梁さ $30 \mathrm{~m}$ までの平均 $\mathrm{S}$ 波 速度 $(\mathrm{m} / \mathrm{s})$ である. $A V S_{30}$ は地形分類と標高上り以下の 経験式 [松岡・翠川 (1994), 翠川・松岡 (1995)］で評価 する.

$$
\log A V S_{30}=a+b \log H
$$

ここで $H$ は標高 $(\mathrm{m}), a, b$ は Table 1 により地形分類に より決まる係数である. 本研究では $500 \mathrm{~m}$ メッシュの 標高データとして, 数値地図 $250 \mathrm{~m}$ メッシュ [国土地

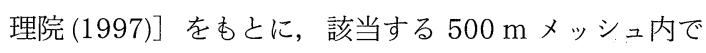
の平均値を使用した. 一方, K-NET の観測点ではPS 検 層による速度デー夕が使用できるため, $A V S_{30}$ の評価に 用いた。 但し, K-NET の観測点では深さ $20 \mathrm{~m}$ までの データしか使用できないため, 司・翠川 (1999) の基準 に従い最下層の值を深さ $30 \mathrm{~m}$ まで外挿して使用した.

$500 \mathrm{~m}$ メッシュ単位での地形分類図の作成は以下の ように行う (Fig. 1). まず県別の地形分類図をスキャ
ナーによりパソコンに取り込む (Fig. 1a). 次に地理情報 システム (GIS) を用いて地形分類図を緯度経度系に合わ せ, 2 分の 1 地域メッシュ (500 m メッシュ) と重ねる (Fig. 1b).さらに各メッシュの代表点 (中心点) から地

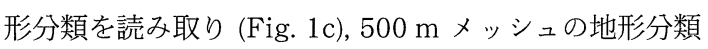
図を作成する (Fig. 1d). ただし，ここでは地形分類図に おいて自然堤防・砂州となっている場合は自然堤防とし ている. Fig. 1e には比較のため国土数值情報の $1 \mathrm{~km}$ メッシュの地形分類図を示しているが, Fig. 1a の地形 分類図や Fig. 1d の $500 \mathrm{~m}$ メッシュ地図に見られる沖 積谷や埋立地などの微細な地形が表現できていないこと

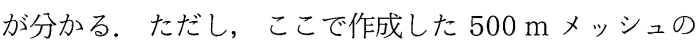
地形分類図では，代表点としてメッシュ中心点を用いて いるため, Fig. 1d に見られるように例えば中心点が河 川である場合,メッシュ全体を河川として評価してしま う.したがってメッシュ内での地形分類図の面積比を考 慮して代表点を決定するなどの改善の余地がある.

同様な作業を全国の地形分類図に対して行い， $500 \mathrm{~m}$ メッシュの地形分類図, さらには Fig. 2 に示すように

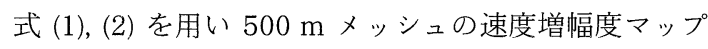
を作成した，さらに地震動評価の例として，次章で説明 する 2000 年 6 月の千葉県北東部の地震を対象とし,

Fig. 3a には距離減衰式を用いた工学的基盤における最 大速度分布を, Fig. $3 \mathrm{~b}$ には地表における最大速度分布 を示す. 表層地盤の増幅特性により基盤上の単純な最大 速度分布が複雑な分布へと変わら, 表層地盤特性の評価 の重要性が分かる。

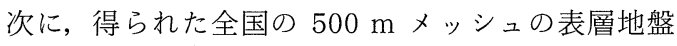
データベースと, 国土数值情報との比較を広い地域を対 象として行う.Fig. 4 には例として関東地方を含む地域 メッシュコード 5339 [日本地図センター (1992)]（80 $\mathrm{km} \times 80$ km, Fig. 3 を参照) を対象として, 国土数值情 


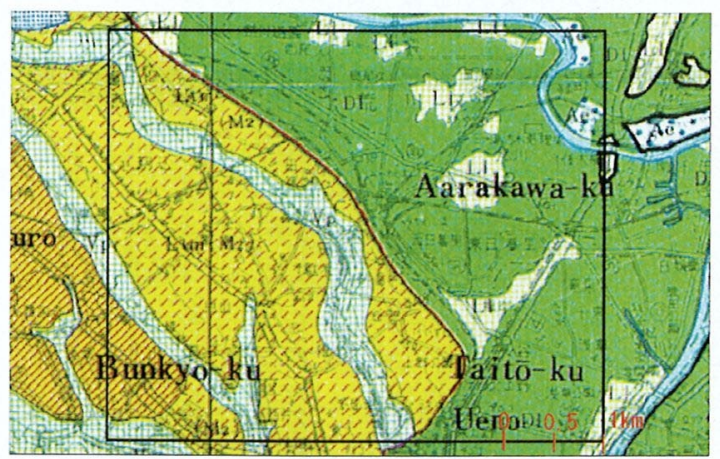

(a) Original Map

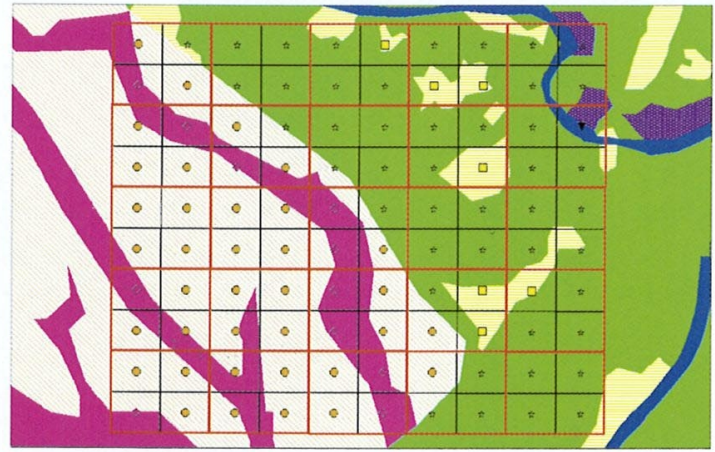

(c) Centers of $500 \mathrm{~m}$ Meshes

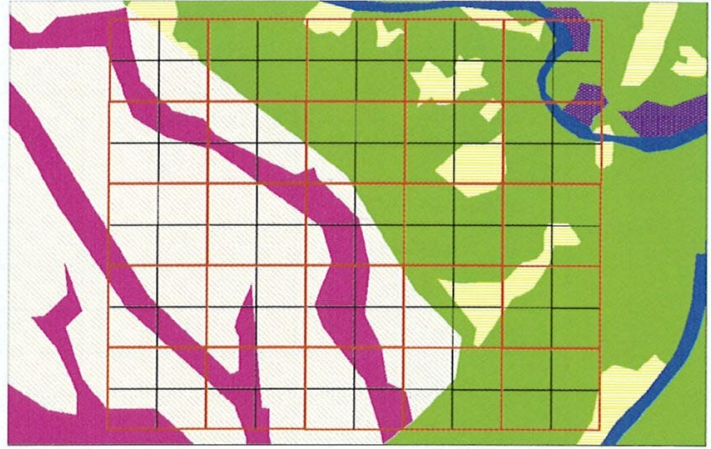

(b) Digitized Map and $500 \mathrm{~m}$ Meshes

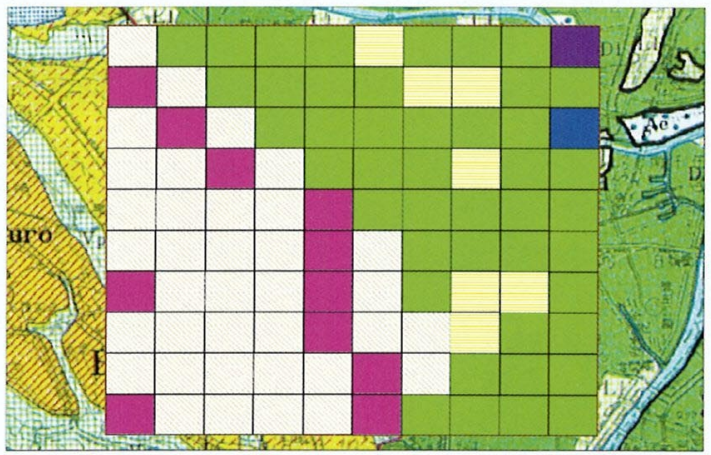

(d) Geomorphological Land Classification by $500 \mathrm{~m}$ Mesh

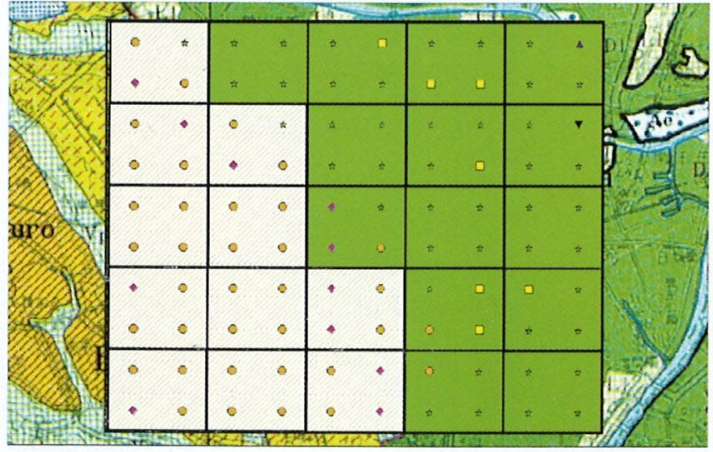

(e) Geomorphological Land Classification by $1 \mathrm{~km}$ Mesh

\begin{tabular}{|c|c|c|}
\hline Classifications & Original map & Mesh \\
\hline Plateau & 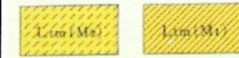 & 0 \\
\hline Delta & Di & \\
\hline $\begin{array}{l}\text { Natural levee } \\
\text { Sand bar }\end{array}$ & & \\
\hline Valley plain & $\mathrm{v}_{\mathrm{p}}$ & \\
\hline Reclaimed & $\because$ & \\
\hline Rivers & & \\
\hline
\end{tabular}

Fig. 1. Maps of the geomorphological land classification in Arakawa-ward, Tokyo. (a) The original map (National Land Agency, 1992). (b) The map digitized from the original map. (c) $500 \mathrm{~m}$ meshes and the central points in each mesh. (d) Dizitized map of $500 \mathrm{~m}$ meshes. (e) Map of the geomorphological land classification of the digital national land information (1 km mesh, Japan Map Center, 1992). 


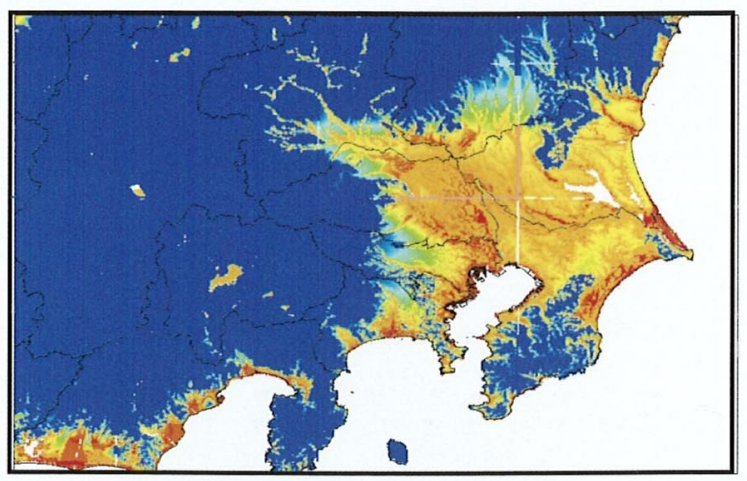

Close up map of the Kanto and Tokai area.

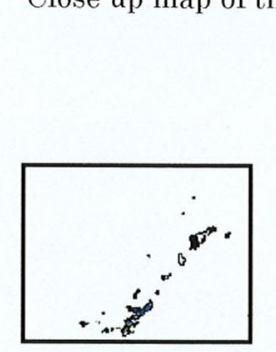

Okinawa Islands

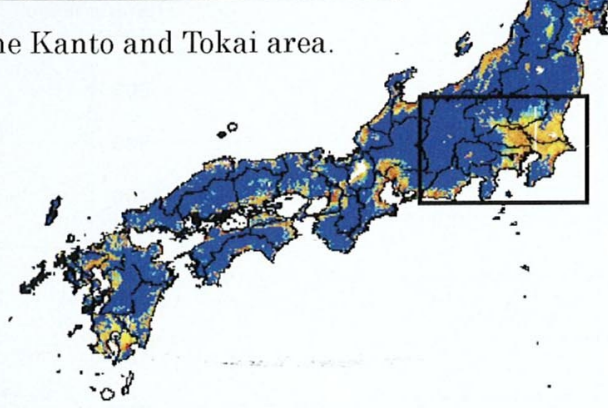

$\because$

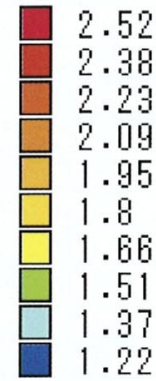

Site amplification factor

Fig. 2. Map of the amplification factor using the $500 \mathrm{~m}$ mesh data.

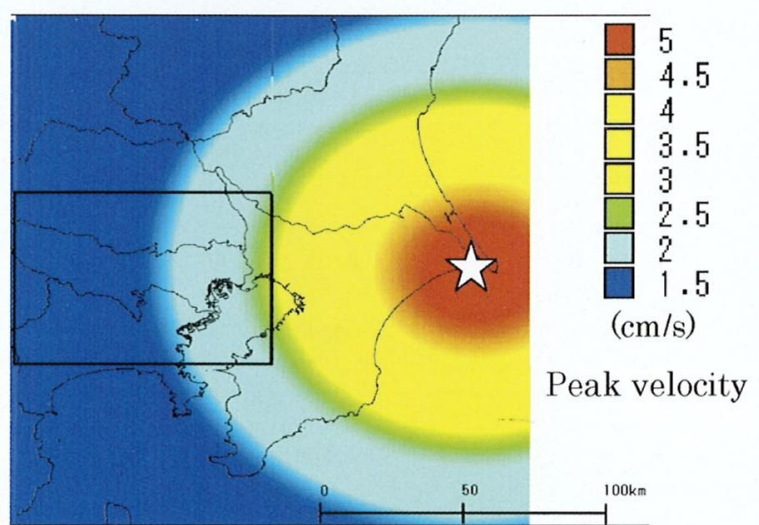

(a) Distribution of peak velocity on engineering bedrock

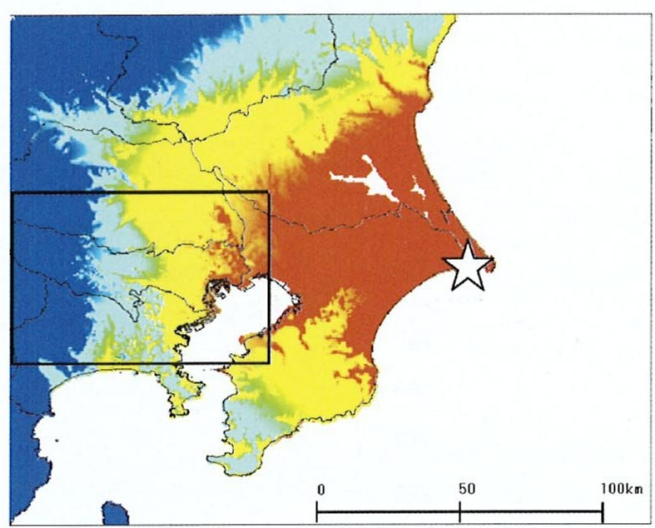

(b) Distribution of peak velocity on free surface

Fig. 3. The distribution of peak ground velocities (a) on bedrock and (b) on surface for the 1996 Off-Chiba earthquake, using the attenuation relation ( $\mathrm{Si}$ and Midorikawa, 1999) and the amplification factors developed in this study. The rectangular area indicates the mesh code 5339 (Japan Map Center, 1992). 
久保智弘・久田嘉章・柴山明寛 $\cdot$ 大井昌弘・石田瑞穂・藤原広行 $・$ 中山圭子
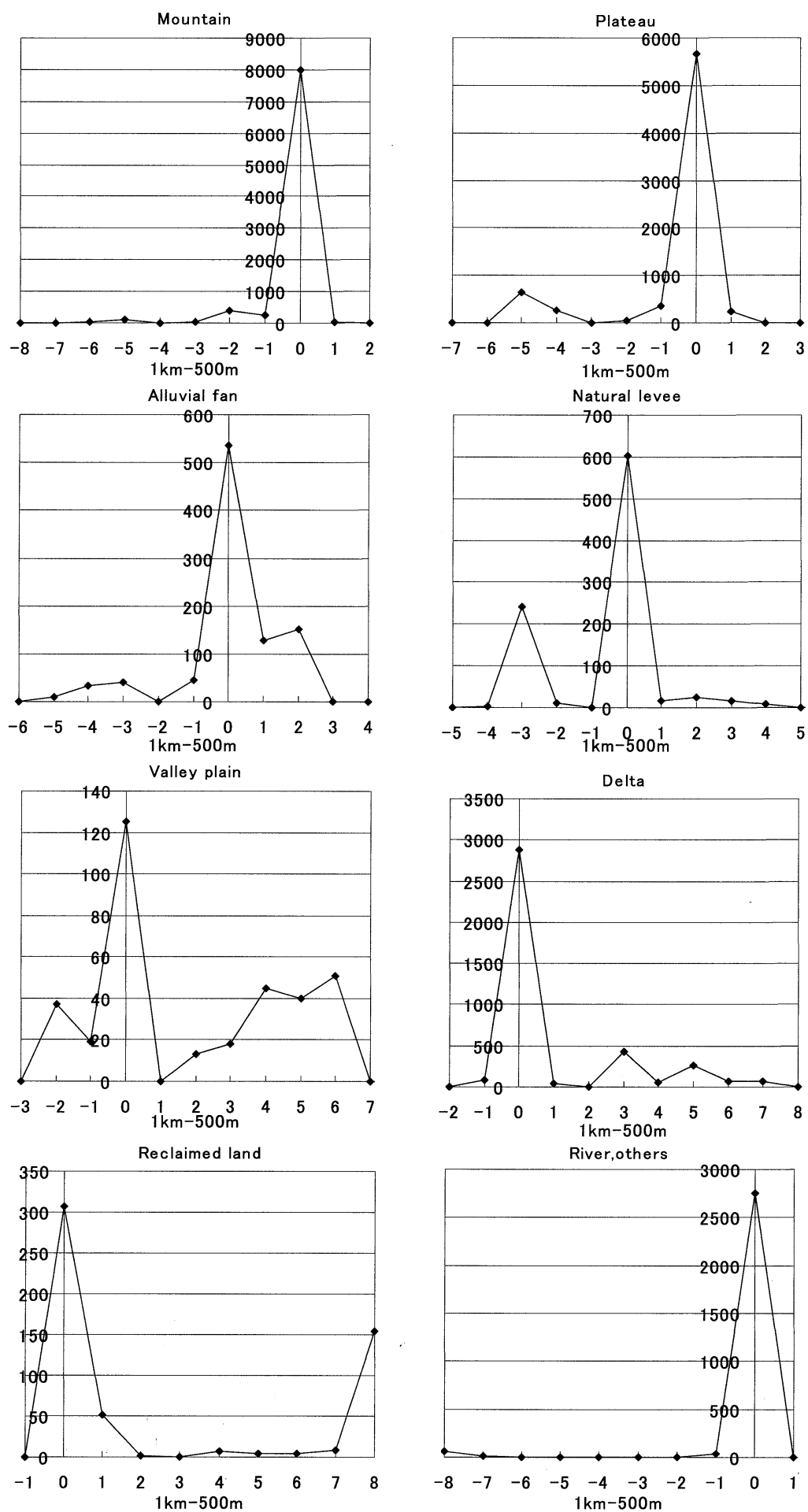

Fig. 4. The distributions of differences of the geomorphological land classification code (see Table. 1) between this study (500 $\mathrm{m}$ mesh) and the digital national land information (1 km mesh). 


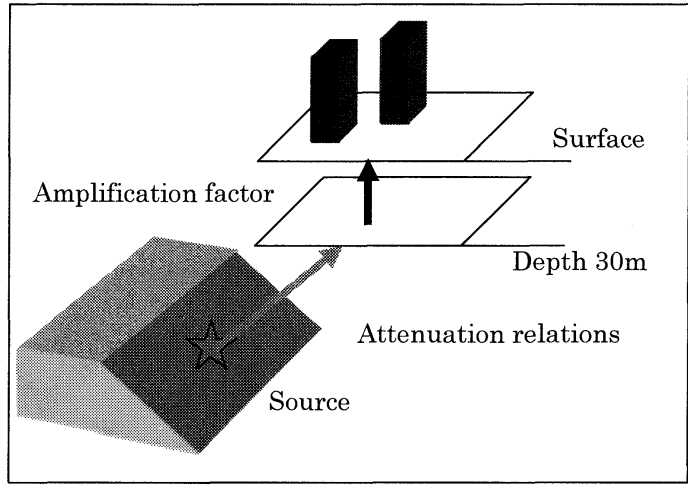

(a) Estimation of peak velocity using the attenuation relation

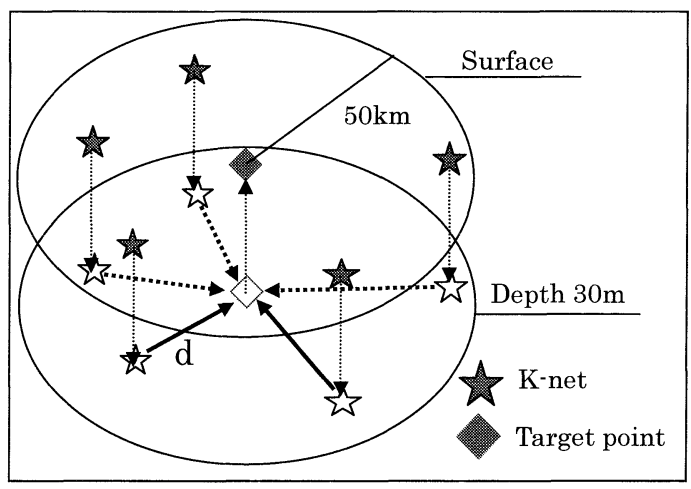

(b) Estimation of peak velocity using strong ground motion records and the interpretation method given by equation.

Fig. 5. The methodologies for estimating the peak ground velocities using (a) the attenuation relation, and (b) the strong motion records.

報の地形分類コード (Table 1) から, 該当する $1 \mathrm{~km}$

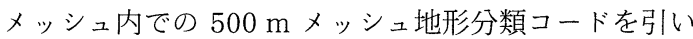
た值を図示する (Fig. 4, 各図の地形分類は $1 \mathrm{~km} メ ッ$ シュによる). 図より，「山地」，「台地」，「河川・その他」 など，地形が比較的単純な地域では，コード差がほぼ 0 に集中しているが，「扇状地」,「自然堤防」,「谷底平野」, 「三角州」などの地形が入り組んでいると考えられる地 域ではコードの差異が目立っている．また「埋立地」で はコード差が 0 の次に 8 の值が目立っているが，これは

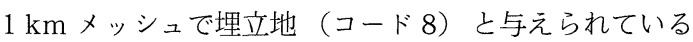
地域が，500 mメッシュでは海や河川（コード 0）と評 価されているためである.

以上のことから既存の国土数值情報と比較し, 本研究

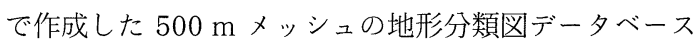
はより微細な地形分類を表現しており, 全国を対象とし
Table 2. The parameters for the attenuation relation (Si and Midorikawa, 1999).

\begin{tabular}{|c|c|c|c|c|c|}
\hline \multirow{2}{*}{ a } & \multirow{2}{*}{$\mathrm{h}$} & \multicolumn{3}{|c|}{ d } & \multirow[b]{2}{*}{ e } \\
\hline & & crustal & inter-plate & intra-plate & \\
\hline 0.58 & 0.0038 & 0 & -0.02 & \begin{tabular}{|l|}
0.12 \\
\end{tabular} & -1.29 \\
\hline
\end{tabular}

た面的な地震動推定に用いるのに有効であるといえる. 次章では，実際に観测された強震記録を用いて，ここで 作成した表層地盤による増幅度のデータベースと, 地震 動推定手法の妥当性を検討する.

\section{§ 3. 地震動推定法}

地震動推定には地震被害想定支援マニュアルをもとに 2つの推定方法を用いる. はじめの手法は震源デー夕か ら距離減衰式を用いて地震動推定を行う方法である.

Fig. 3 および Fig. $5 \mathrm{a}$ に示すように，まず工学的基盤上 の最大速度を求め，(1) 式による表層地盤による増幅度 を乗じて地表面における最大速度を求める. 距離減衰式 として，ここでは司・翠川 (1999)を用いる.

$$
\begin{aligned}
& \log V=b-\log (X+c)-k \times X \\
& c=0.0028 \times 10^{0.50 \times M w} \\
& b=a \times M w+h \times D+\sum d i \times S i+e \\
& k=0.002
\end{aligned}
$$

ここで, $V$ は最大速度值 $(\mathrm{cm} / \mathrm{s}), X$ は断層面からの最短 距離 $(\mathrm{km}), k$ は粘性減衰係数, $M w$ はモーメントマグニ チュード, $D$ は震源深さ $(\mathrm{km}), a, h, d i, e$ は Table 2 よ り求まる係数である. Si はダミ一変数で, 断層夕イプか ら決まる係数であり, 断層の夕イプは, 地殼内地震, プ レート間地震, プレート内地震と分類されている. (3) 式 は同じ距離にある場合, プレート間地震, 地殼内地震, プレート内地震の順番で最大速度值が大きくなる特徵が ある.

もう一つの地震動推定法は, 強震観測デー夕を補間し て任意点に抢ける地震動を求める方法である. Fig. $5 b$ に示すように，この方法では，まず観測された各点にお ける強震観測データの最大速度值を, それぞれの地盤増 幅度で除して工学的基盤上での最大速度值を求める. 次 に, 求めたい任意点から最大 $50 \mathrm{~km}$ 以内かつ最大 5 点 の観測点における工学的基盤上の最大速度値を用いて,

(4) 式による距離の重み付けを行い, 任意点における最 大速度值を算出する. 最後にその任意点における増幅度 を乗じて地表面における最大速度の推定值を求める.

$$
V_{b}=\frac{\sum_{i=1}^{5} \frac{V_{b i}}{d_{i}}}{\sum_{i=1}^{5} \frac{1}{d_{i}}}
$$

ここで, $V_{b}$ と $V_{b i}$ は任意点と $i$ 観測点における工学基盤 
Table 3. Catalog of the three earthquakes used in this study.

\begin{tabular}{|c|c|c|c|c|c|c|}
\hline Earthquake & Date & Longitude & Latitude & Depth $(\mathrm{km})$ & Mw & Mima \\
\hline Off Chiba & $1996 / 9 / 11$ & 141.3 & 35.7 & 59 & 6.1 & 6.6 \\
\hline Tokyo bay & $1998 / 8 / 29$ & 140 & 35.6 & 56 & 5.3 & 5.4 \\
\hline Chiba Northeastern & $2000 / 6 / 3$ & 140.8 & 35.7 & 50 & 6.1 & 5.8 \\
\hline
\end{tabular}

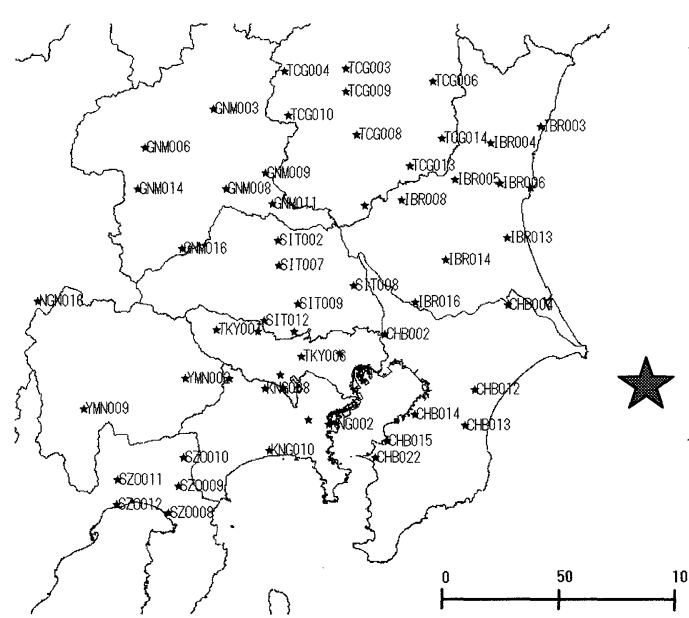

(a) 1996 Off Chiba Earthquake

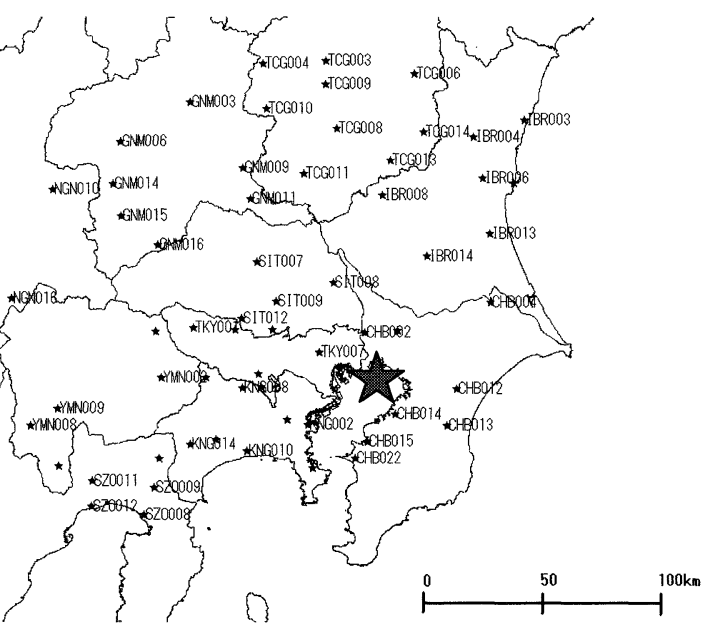

(b) 1998 Tokyo Bay Earthquake

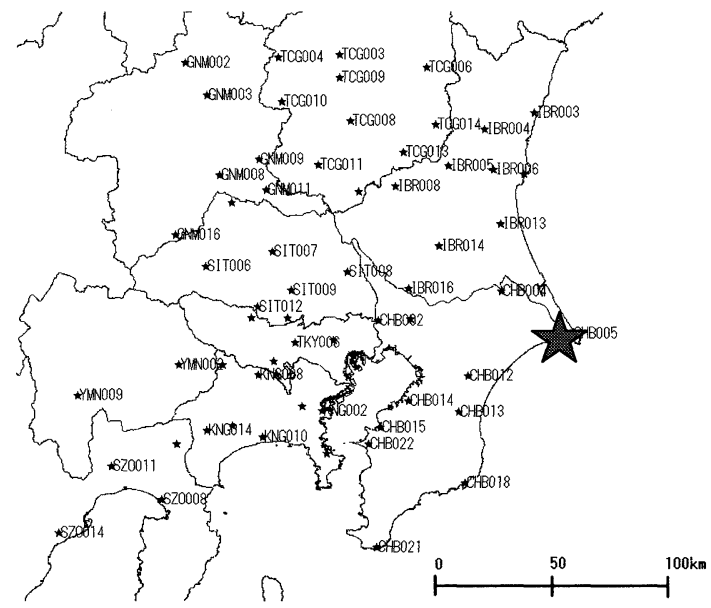

(c) 2000 Northeastern Chiba Earthquake

面での最大速度值， $d_{i}$ は任意点と $i$ 観測点間の距離を表 す.この補間推定法は, 観測值の抽出が機械的に行える ため，即時的な地震動推定に適している.

地震動推定に必要な表層地盤による増幅度は § 2. で 述べた PS 検層デー夕の平均 S 波速度から計算したもの

と, 地形分類と標高から算出したものの 2 つの方法を用 い, 比較検討する.

震度 $I$ は, 地震被害想定支援マニュアル [内閣府
Fig. 6. The locations of the epicenters and the K-Net stations for (a) Off Chiba, (b) Tokyo bay, and (c) Northeastern Chiba earthquakes.

(2001)］に従い, 最大速度值 $V$ から次式を用いて推定す る.

$$
I=2.02 \times \log V+2.4
$$

一方, K-NET の強震記録から計測震度を計算し, 面的 な震度推定を行う場合は，(5) 式を用いて各観測点の最 大速度に変換し，上記の補間法を用いて行う。 


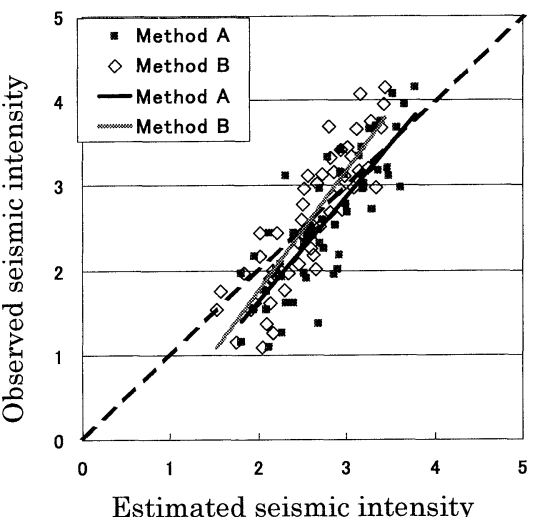

(a) 1996 Off Chiba Earthquake

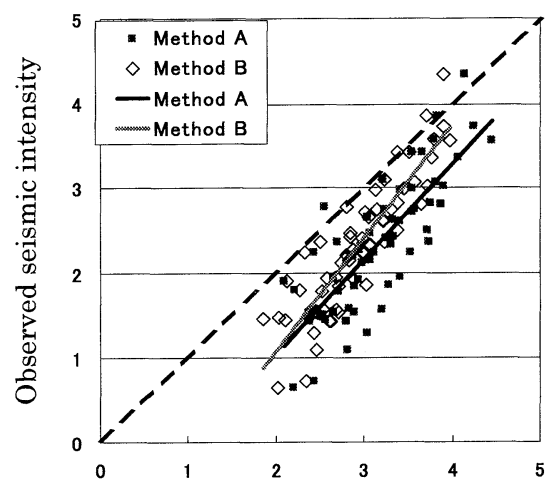

Estimated seismic intensity

(c) 2000 Northeastern Chiba Earthquake

\section{§4．表層地盤特性と地震動推定法の検討}

\section{1 対象とする地震と強震観測データ}

上記に示した表層地盤特性のデータと地震動評価法を 用いた推定值と，実際に観測された強震記録を比較する ことによって手法の妥当性を検討する，近年，関東地方 で観測された地震記録のうち広範囲な地域でデータが得 られた Table 3 に示す 3 つの地震を選んだ。表の震源 パラメー夕は, 千葉県東方沖地震では東京大学地震研究 所 (1996)より, 東京湾の地震および千葉県北東部地震 では防災科学技術研究所の F-netによる值 [防災科学技 術研究所 (1998), (2000)] を用いた. Fig. 6 にそれぞれ の地震で使用する K-NET の観測点および震源位置を示 す.

本研究での地震動の比較は, 最も簡便な強震動の尺度 の一つである観測震度と推定震度で行う。すなわち, 観 測震度は K-NET により観測された加速度波形から定義 通り [気象庁 (1996)］に計算した計測震度を用い，推定 震度は推定した地表最大速度から (5) 式により算出した 震度を用いる。

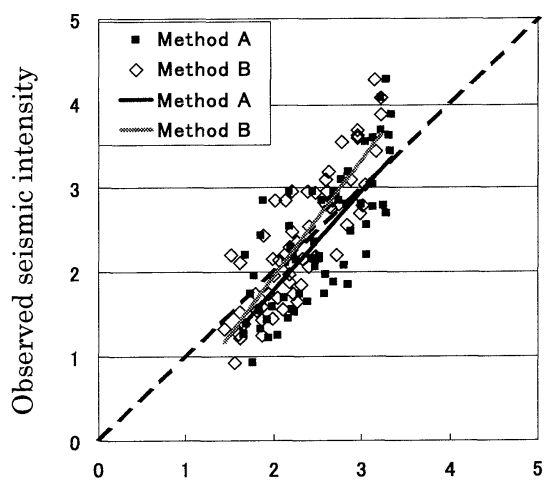

Estimated seismic intensity

(b) 1998 Tokyo Bay Earthquake

Fig. 7. The comparisons of seismic intensities between the observations and the estimations using the attenuation relation, for the (a) Off Chiba (b) Tokyo bay (c) Northeastern Chiba earthquakes. Methods $\mathrm{A}$ and $\mathrm{B}$ correspond to the amplification factors evaluated by the geomorphological land classification data and the boring data, respectively.

\section{2 距離減衰式による推定結果}

距離減衰式は司・翠川 (1999)による (3) 式を用いる が, Table 2 のパラメー夕 d を決定するための断層タイ プは, 対象とした地震の震源の深さが $50 \mathrm{~km}$ から 59 $\mathrm{km}$ と深いため, ここでは地震直後における早期の地震 動推定を目的とすることから，推定値が安全側に（大き めに）評価されるようにすべてプレート内地震とした.

Fig. 7 は, 横軸に距離減衰式と (5) 式により求めた推 定震度をとり，縦軸に観測された計測震度をとった時の 散布図である．図中，地形分類図による増幅度を使用し た結果 (Method A とする) を黒印で，それらの最小二 乗法による近似線を太い線で示した. また, PS 検層デー 夕による增幅度を使用した結果（Method B とする）を 白印で, 散布図の最小二乗法による近似線を細い線で示 している. 正解值である対角線（破線）と比較すると, 千葉県東方沖地震や東京湾の地震では, どちらの増幅度 を用いても推定結果にはそれほど違いが見られないが，

Fig. $7 \mathrm{c}$ の千葉県北東部の地震では, 推定結果が過大評 価となっている. したがって距離減衰式による地震動推 
Table 4. The correlation coefficients from Fig. 7, the average errors of the estimated seismic intensities, and the standard deviations from Fig. 8, for the (a) Off Chiba (b) Tokyo bay (c) Northeastern Chiba earthquakes. Methods $\mathrm{A}$ and $\mathrm{B}$ correspond to the amplification factors evaluated by the geomorphological land classification data and the boring data, respectively.

\begin{tabular}{|c|c|c|c|c|c|c|}
\hline & \multicolumn{2}{|c|}{ Correlation coefficient } & \multicolumn{2}{c|}{ Average of error } & \multicolumn{2}{c|}{ Standard deviation of error } \\
\hline Earthquake & Method A & Method B & Method A & Method B & Method A & Method B \\
\hline Off Chiba & 0.824 & 0.876 & 0.196 & 0.002 & 0.455 & 0.424 \\
\hline Tokyo bay & 0.772 & 0.850 & 0.132 & -0.066 & 0.498 & 0.434 \\
\hline Chiba Northeastern & 0.810 & 0.888 & 0.833 & 0.623 & 0.457 & 0.393 \\
\hline
\end{tabular}

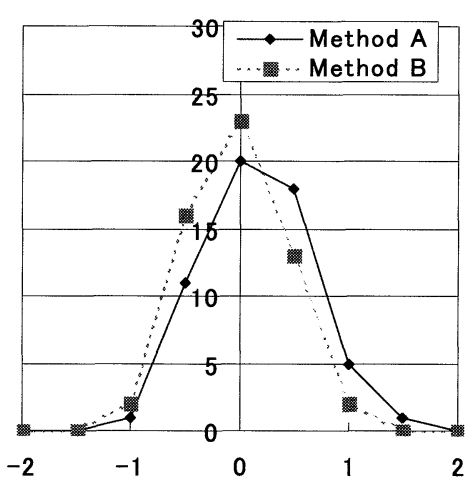

Error of estimated seismic intensity

(a) 1996 Off Chiba Earthquake

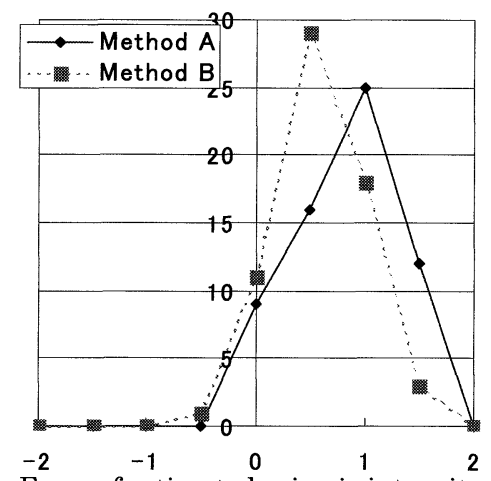

Error of estimated seismic intensity

(c) 2000 Northeastern Chiba Earthquake

定は不安定な結果を示すことが分かる.

Fig. 8 は推定震度から観測震度の值を引いた䛊差の ばらつきの分布図を示したものである. 図中, 地形分類 図による増幅度を使用した結果を実線で, PS 検層デー 夕による増幅度を使用した結果を破線で示す。また,

Table 4 は, Fig. 7 の散布図から求めた相関係数之, Fig. 8 の分布図から求めた誤差の平均值および標準偏 差を示す. Fig. 8 では, 千葉県東方沖地震や東京湾の地 震ではほぼ誤差が 0 軸に近いところにデータが集中し ているが, Fig. 8c の千葉県北東部の地震では推定值が

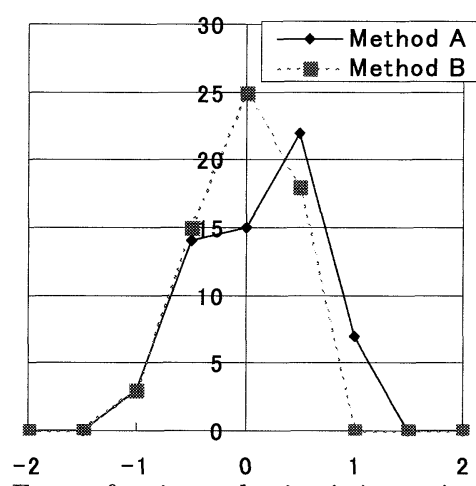

Error of estimated seismic intensity

(b) 1998 Tokyo Bay Earthquake

Fig. 8. The distributions of the errors of the estimated seismic intensities as compared with the observed seismic intensities, for the (a) Off Chiba (b) Tokyo bay (c) Northeastern Chiba earthquakes (from Fig. 7).

過大に評価されているため， +1 付近にデータが集中し ている．また地形分類図 (Method A) と PS 検層デー夕 (Method B) による結果を比較すると後者の方が誤差は 0 に近いことがわかる. また Table 4 より, いずれの地 震でもPS 検層データによる結果が地形分類図による結 果よりも高い相関係数を示し, 誤差の平均值と分散も小 さな值となっている. また千葉県北東部の地震では誤差 の值が大きく, 推定值が過大に評価されていることが分 かる.

以上のことから，距離減衰式と表層地盤特性を考慮し 


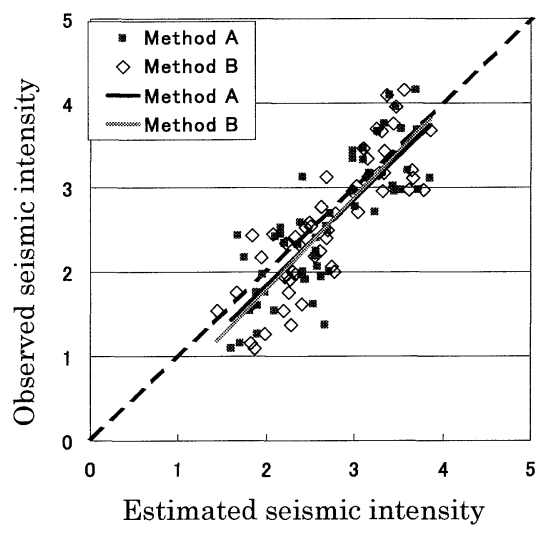

(a) 1996 Off Chiba Earthquake

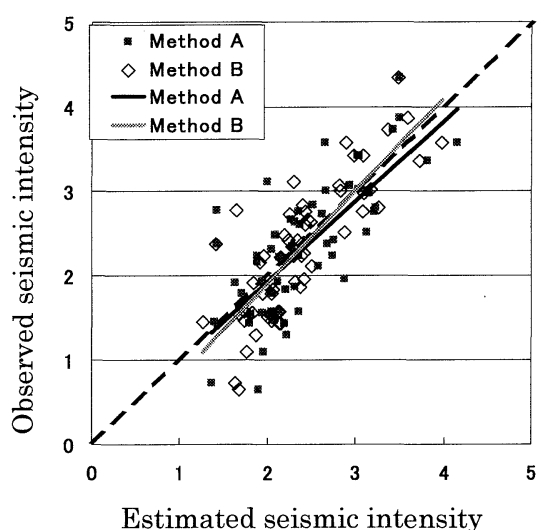

(c) 2000 Northeastern Chiba Earthquake

た地震動推定法を用いると，簡便に面的な地震動推定が 行え，かつ比較的良好な推定結果が得られるものの，場 合によっては結果が大きな䛊差を与えるなど不安定な結 果を示すことが分かった。ここで使用した距離減衰式は あくまであ全国の平均的なものであるため，地域ごとの 震源・伝播・地盤特性を考慮して, より精度の高い屯の に改善していくことが望ましい. 一方, PS 検層データに よる増幅度を用いた場合の地震動推定の精度は，地形分 類図による増幅度を用いた場合よりも精度が高いことも 確認できた.

\section{3 強震動データの補間による推定結果}

Fig. 9 は Fig. 7 と同様に, 対象とする観測点の周辺 の強震動データから (4) 式による補間法を用いて推定し た震度を横軸にとり，対象とする観測点の観測された計 測震度を縦軸にとった時の散布図を示す。地形分類困に よる結果 (Method A) を黒印で，それらの最小二乗法に よる近似線を太い線で示し, 一方, PS 検層デー夕による 結果 $($ Method B) を白印，それらの最小二乗法による近 似線を細い線で示している. Fig. 7 と比べると, ややば

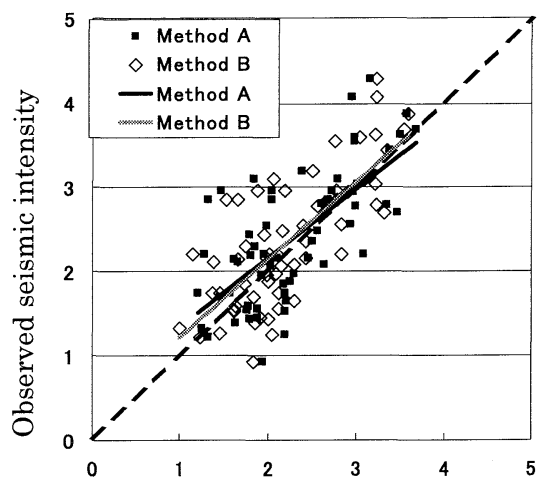

Estimated seismic intensity

(b) 1998 Tokyo Bay Earthquake

Fig. 9. The comparisons of seismic intensities between the observations and the estimations using strong motion records, for the (a) Off Chiba (b) Tokyo bay (c) Chiba Northeastern earthquakes. Methods A and $\mathrm{B}$ correspond to the amplification factors evaluated by the geomorphological land classification data and the boring data, respectively.

らついているものの, 正解值である対角線上に近く, ど の地震であ安定した結果を示している.

Fig. 10 は観測值と推定值の誤差の分布図を, Table 5 は相関係数, 䛊差の平均值, および標準偏差を示す.

Fig. 10 から，いずれの地震でも誤差が 0 軸に集中して いることがわかる。 また地形分類図と PS 検層デー夕に よる結果を比較すると, Table 5 に見られるように後者 の方が相関係数の高さや，標準偏差の小ささなどから良 好な結果を示している. 一方, 距離減衰式を用いた結果 (Fig. 8, Table 4) と比較すると, 強震動デー夕による推 定結果はばらつき(標準偏差) がやや大きくなっている. これは距離減衰式では, 対象とするサイトの堌幅度を一 度だけ用いるのに対し, 補間法では対象とするサイトの 増幅度に加え, 周辺の観測点 (最大 5 点) における増幅 度あ用いるため, 経験式である (1) 式の䛊差がより大き く評価されてしまうためだと考えられる. したがって観 測点ごとの増幅度の精度を向上させることが今後の重要 な課題である.

以上のことから強震動データを用いた推定結果は, 距 


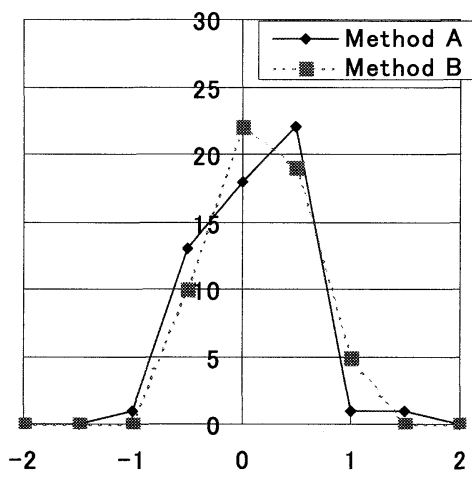

Error of estimated seismic intensity

(a) 1996 Off Chiba Earthquake

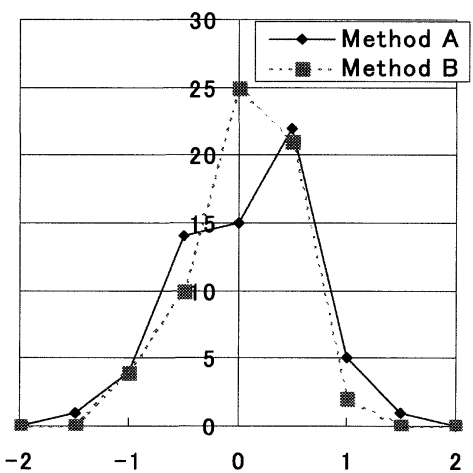

Error of estimated seismic intensity

(c) 2000 Northeastern Chiba Earthquake

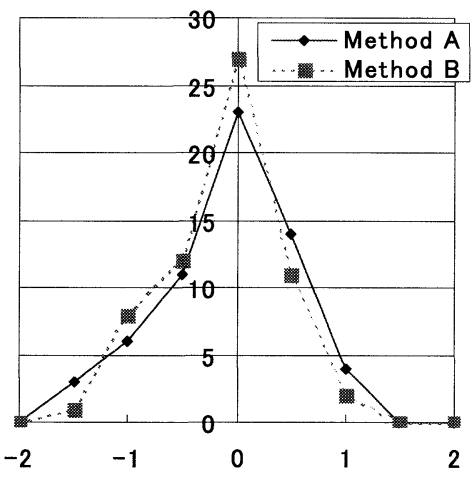

Error of estimated seismic intensity

(b) 1998 Tokyo Bay Earthquake

Fig. 10. The distributions of the errors of the estimated seismic intensities as compared with the observed seismic intensities, for the (a) Off Chiba (b) Tokyo bay (c) Northeastern Chiba earthquakes (from Fig. 9).

Table 5. The correlation coefficients from Fig. 9, the average errors of the estimated seismic intensities, and the standard deviations from Fig. 10, for the (a) Off Chiba (b) Tokyo bay (c) Northeastern Chiba earthquakes. Methods A and B correspond to the amplification factors evaluated by the geomorphological land classification data and the boring data, respectively.

\begin{tabular}{|c|c|c|c|c|c|c|}
\hline & \multicolumn{2}{|c|}{ Correlation coefficient } & \multicolumn{2}{c|}{ Average of error } & \multicolumn{2}{c|}{ Standard deviation of error } \\
\hline Earthquake & Method A & Method B & Method A & Method B & Method A & Method B \\
\hline Off Chiba & 0.818 & 0.856 & 0.140 & 0.140 & 0.446 & 0.405 \\
\hline Tokyo bay & 0.693 & 0.757 & -0.103 & -0.122 & 0.574 & 0.512 \\
\hline Chiba Northeastern & 0.734 & 0.818 & 0.096 & 0.065 & 0.524 & 0.447 \\
\hline
\end{tabular}

離減衰式のように震源データや伝播特性の精度に依存し ないため，安定した結果を示すことが確認された。また 距離減衰式による場合と同様に, PS 検層データによる 増幅度の方が地形分類図による増幅度より精度が高いこ とも確認できた。

\section{4 気象庁震度との比較}

最後に, 推定した面的な震度と気象庁発表の計測震度 と比較検討する. 推定する面的震度分布として, 上で説 明した距離減衰式を用いた方法と, K-NET の最大速度 から補間法を用いて推定した方法とに加え，K-NET か
ら計測震度を計算し，それを補間して推定した方法，の 3 ケースを比較する。 K-NETにおける計測震度の補間 法は, (5) 式を用いて最大速度に変換してから行う. 参考 として Fig. 11 に 1996 年東京湾の地震と 2000 年千葉 県北東部地震に対して, 観測した最大速度値と, 計測震 度から速度值に変換した值とを比較する．また，ここで は表層地盤の増幅度はすべて地形分類によるものを使用 する. この地震の場合, 図上り計測震度から变換した速 度值は, 実際の最大速度值よりやや大きめに評価される 傾向が見られる. 


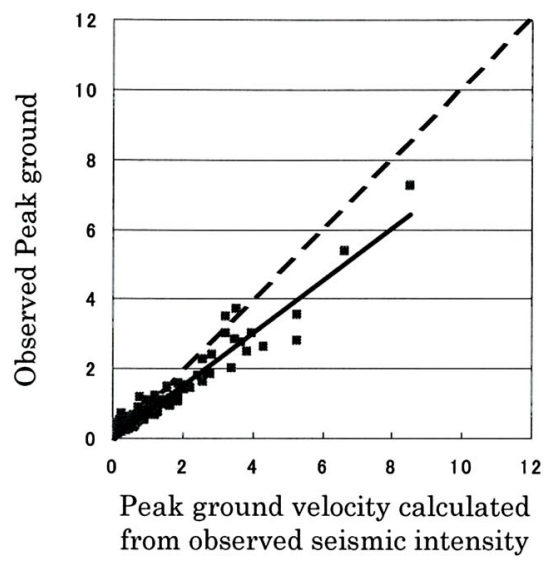

(a) 1998 Tokyo Bay Earthquake

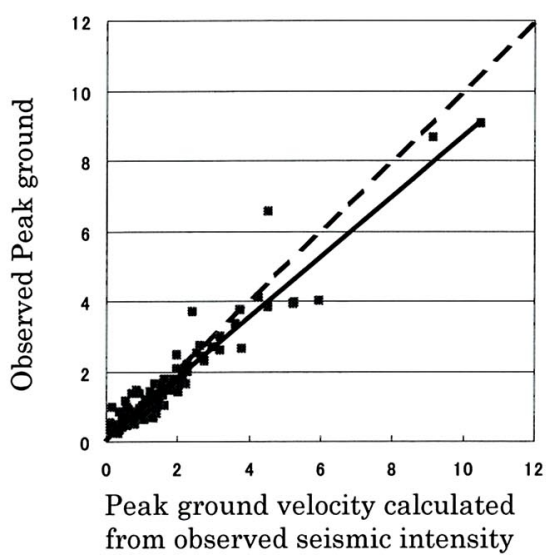

(b) 2000 Northeastern Chiba Earthquake

Fig. 11. The comparisons of peak ground velocities between the observations and the calculations using the observed seismic intensities, for (a) Tokyo bay (b) Northeastern Chiba earthquakes.

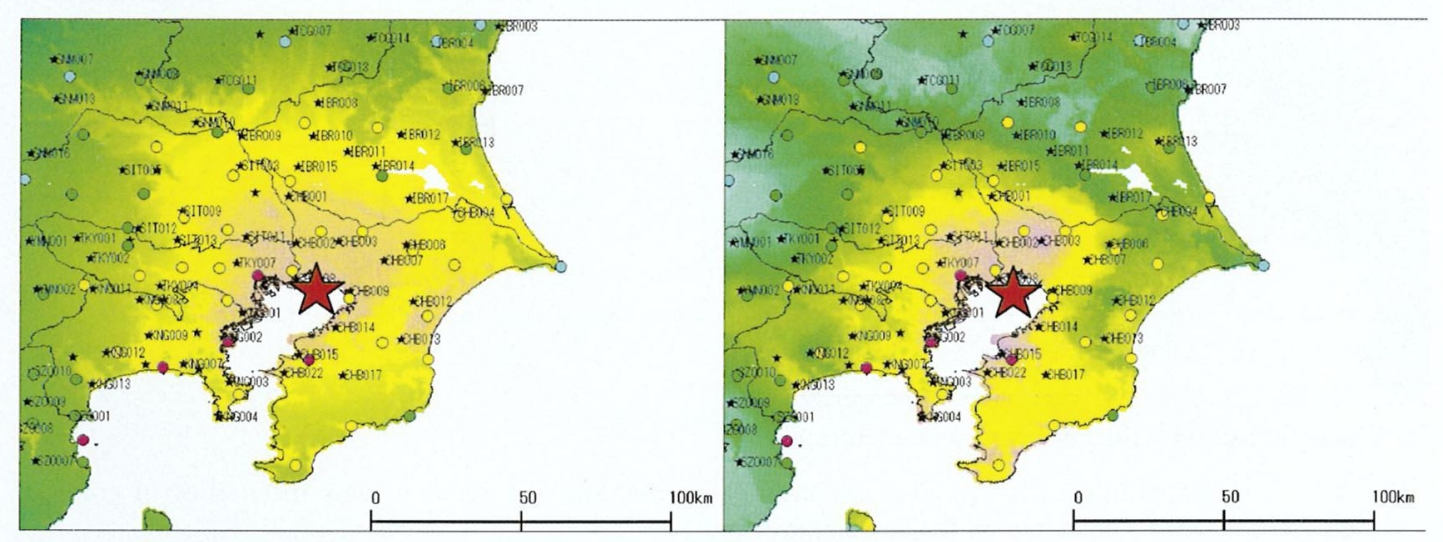

(a) The estimation by the attenuation relation

(b) The estimation by the strong ground motion re-

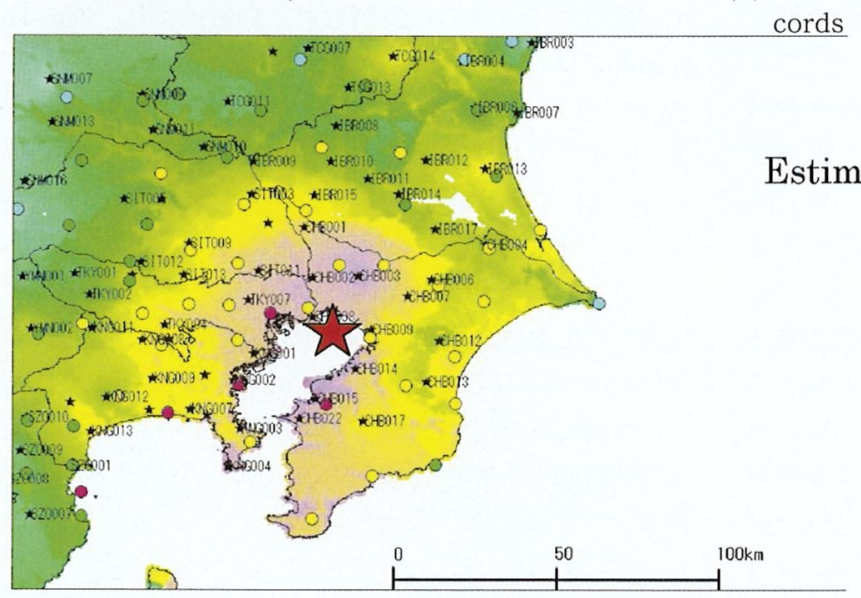

ords

(c) The estimation by the observed seismic intensities

Fig. 12. The distribution of estimated seismic intensities and the seismic JMA intensities of colored circles for 1998 Tokyo Bay Earthquake. 


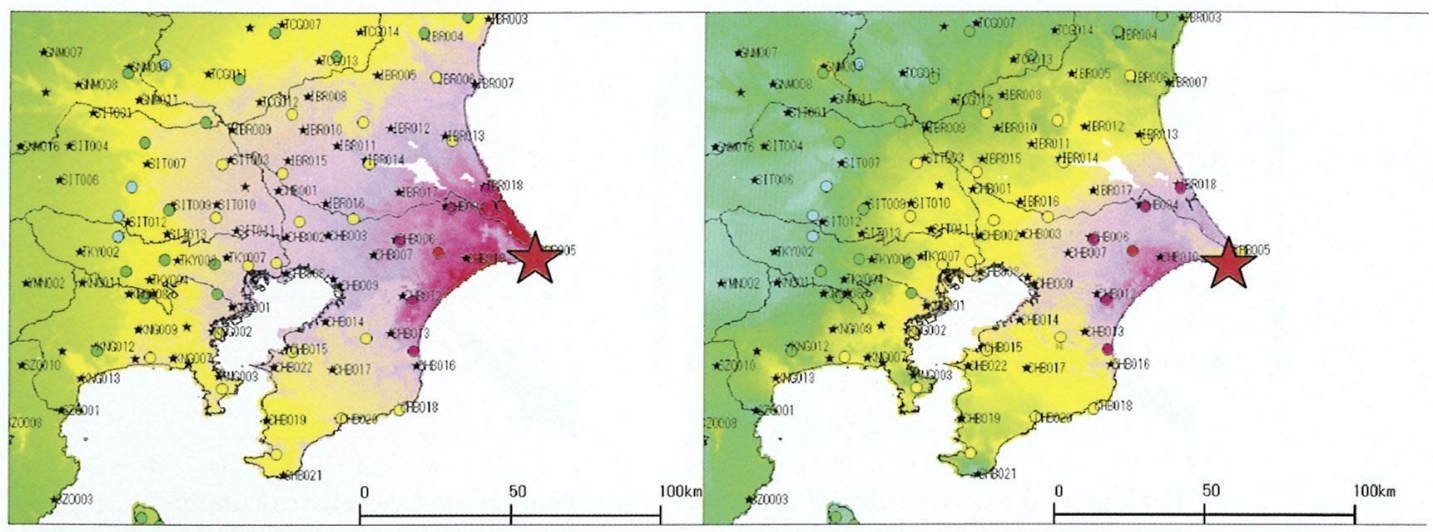

(a) The estimation by the attenuation relation

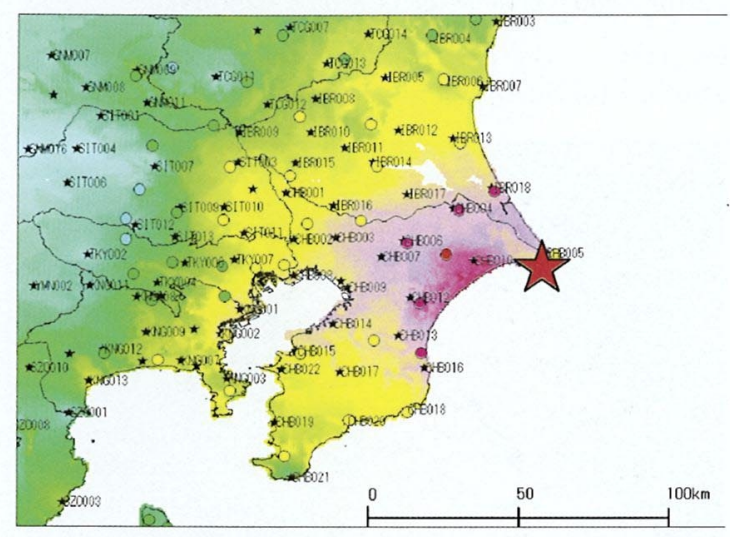

(b) The estimation by the strong ground motion records

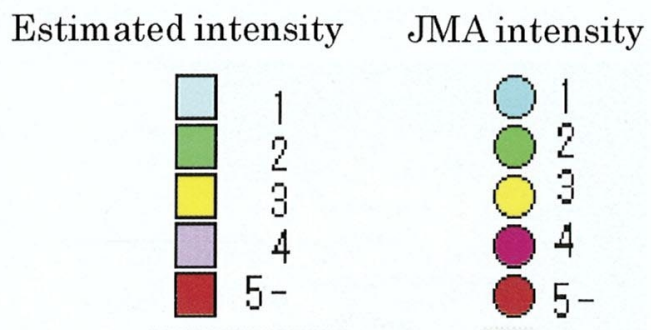

(c) The estimation by the observed seismic intensities

Fig. 13. The distribution of estimated seismic intensities and the seismic JMA intensities of colored circles for 2000 Northeastern Chiba Earthquake.

次に Fig. 12 と Fig. 13 には，それぞれ 1996 年東京 湾の地震, および 2000 年千葉県北東部地震について, 距離減衰式を用いた震度分布と K-NET の最大速度を用 いた震度分布，および K-NET の計測震度を用いた震度 分布を示す．図には気象庁発表による計測震度の值も同 じスケールで示している[地震予知総合研究振興会 (1998), (2000)]．Fig. 12 では 3 手法による違いは明瞭 ではないが, Fig. 13 では距離減衰式による推定結果は 関東平野全域で過大な評価となっている。一方, 他の 2 手法では明瞭な差は見られない，さらに 2 つの地震につ いて Fig. 14 と Fig. 15 に, 横軸に気象庁の計測震度を とり, 縦軸には 3 手法で推定した震度をとった比較を示 す. 気象庁の計測震度は 5 弱を 4.7 とし, その他は $1 \sim 4$ の整数值としている. 各計測震度に対する推定震度の平 均值を四角, 標準偏差を横棒, および最小・最大值を丸 印とし，それぞれ図中に示している，各図にある数值は， 気像庁の計測震度に対する推定震度の誤差の平均值を示 している.これらの図から, 全体的に低い震度では, 推
定震度はやや大きめに評価されている，また，Fig. 15 で顕著に見られるように，K-NET の最大速度值と計測 震度を用いた推定結果は, 距離隇衰式から推定した結果 より安定しており, 正解值である対角線上に近い值を示 している. また, 計測震度から推定した結果は, 最大速 度による推定結果よりも䛊差はやや大きくなっている。

これは使用した表層地盤の増幅度が最大速度値の増幅度 に対応しており, より広い周期帯域を持つ計測震度には 対応できていないことが一因と考えられる。したがっ て, 計測震度を用いて面的な地震動推定を行う場合, 計 測震度に関する地盤の増幅特性を適切に評価する必要が ある。

\section{§5. 議論およびまとめ}

本研究では全国を対象に, 地震直後において地震動推 定を早期に行うことを前提として, 表層地盤特性を考慮 した地震動推定を行い, 関東平野を対象に実際に観測さ れた強震記録との比較からその精度を検討した。 まず全 


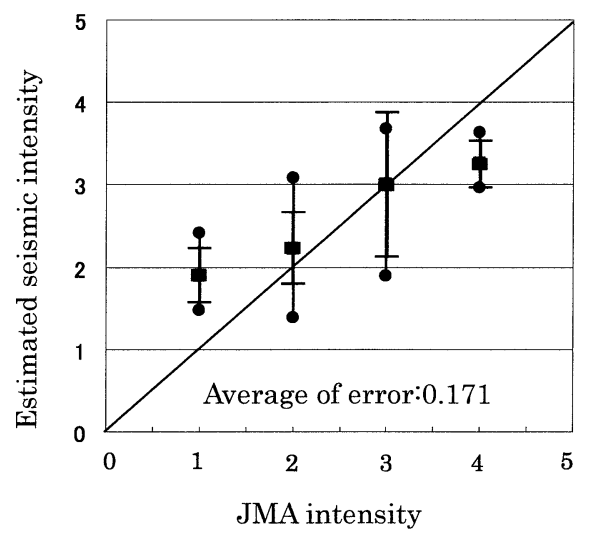

(a) The estimation by the attenuation relation

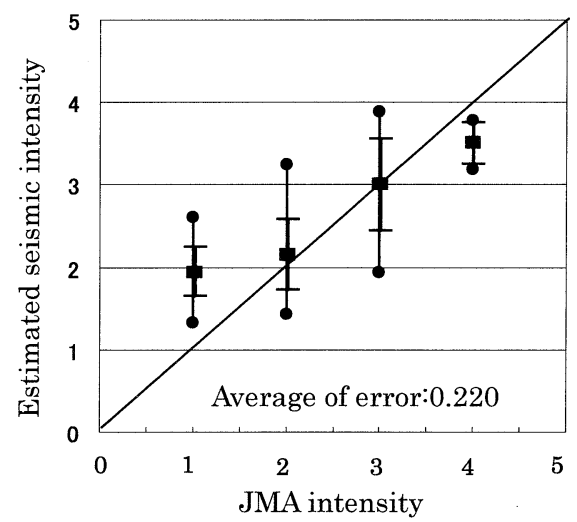

(c) The estimation by the observed seismic intensities

国の表層地盤特性のデータベースを作成するため，地形

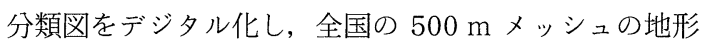
分類図と，地震被害想定支援ツール [内閣府 (1999)］を 用いた表層地盤による速度の増幅度マップを作成した。

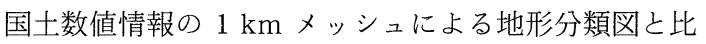
べると，ここで作成した地形分類図は谷底平野など微細 に入り組んだ地形む評価でき，より解像度の高いデー夕 ベースとなっていることを確認した。

次にデジタル化した増幅度マップを用いて, 距離減衰 式抢よび強震動デー夕による補間法を使用した地震動 (震度) の推定を行い, 実際に観測された強震記録による 計測震度との比較から精度を検討した。 その結果, 強震 観測デー夕による推定結果は, 距離減衰式のように震源 データや伝播特性の精度に依存しないため, より安定し た結果を示すことが確認された。一方, 計測震度を用い て面的な地震動推定を行う場合, 計測震度に対応した地 盤の増幅特性を評価する必要があることも明らかとなっ た。

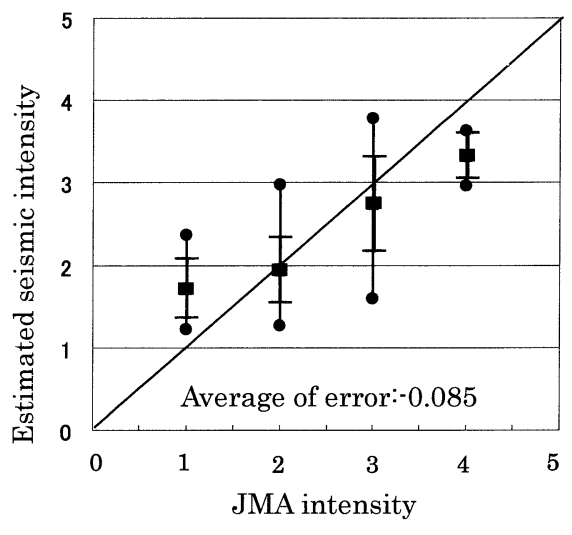

(b) The estimation by the strong ground motion records

Fig. 14. The comparisons of seismic intensities between the observations by JMA and the estimations by this study, for the 1998 Tokyo Bay Earthquake. The rectangular marks, the horizontal bars, and the solid circles are the averages, the standard deviations, and the minimum/maximum values of the estimations, respectively.

以上より地震直後の即時的地震動推定を行う場合, ま ず震源情報が得られた段階で，距離減衰式による暫定的 な地震動推定を行い, その後, 強震動デー夕が得られた 段階で逐次強震動デー夕による推定結果に置き換えて行 くことが有効であると考えられる. 特に地震発生後しば らくは, 被害の甚大な地域からは強震動デー夕が入手で きない可能性があるため, 強震動デー夕が利用できるま で距離減衰式による推定結果を有効に活用すべきであ る、今後, 距離減衰式を用いてより安定した結果を得る ためには, 高精度の震源パラメー夕に加えて, 地下構造 などの地域特性を適切に評価する必要がある。したがっ て地域ごとの補正項を距離減衰に導入するなどの検討が 必要になると考えられる.

一方，地形分類図による地盤増幅度と，K-NET 観測 点における PS 検層デー夕による增幅度を比較すると, 後者の方が高い精度を示すことも確認した，最近では K-NET などの強震動デー夕を利用し，地域特性を考慮 した地盤特性デー夕む作成されている [例えば，伊藤・ 


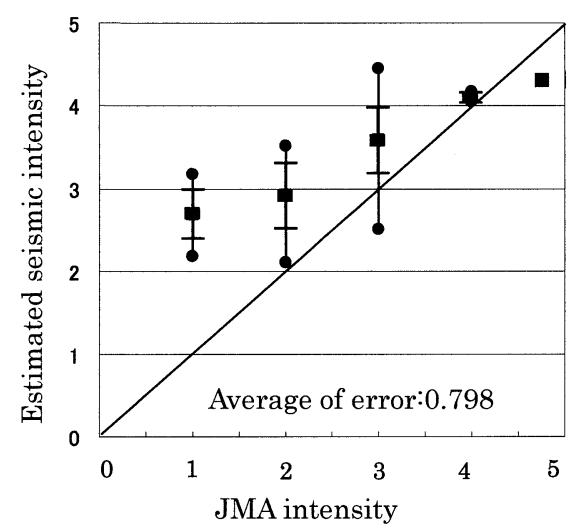

(a) The estimation by the attenuation relation

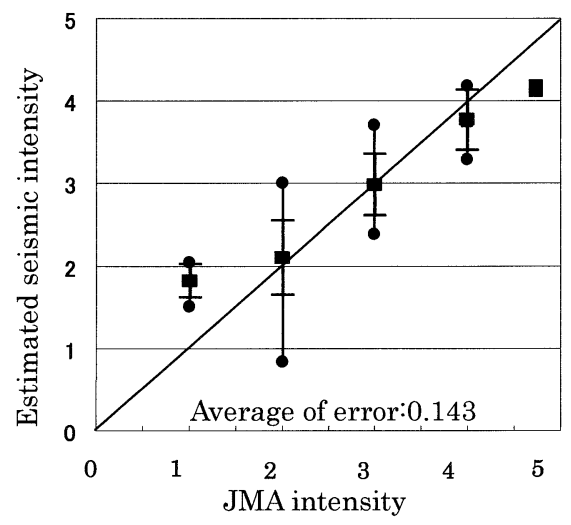

(c) The estimation by the observed seismic intensities

川瀬 (2001), 加藤 (2001), 福和・他 (1999) など].さら に計測震度に対応した地盤の増幅特性の評価も行われて いる[例えば大西・他 (1999)]. したがって, 様々な地域 で PS 検層データや強震動記録を用いて，より精度の高 い地盤増幅特性のデータベースを作成し, 順次データ ベースのバージョンアップを図る必要がある．また自治 体でも地震被害想定の実施の際, PS 検層デー夕等が整 理されているため, それらのデータも有効に活用すべき である.

な抢本研究でデジタル化したデータベースは一般に公 開されているため, 使用を希望する場合, 著者まで連絡 されたい.

\section{謝辞}

本研究で地形分類のデジタル化を行うにあたり, 工学 院大学の今北統夫氏, 佐久間景子氏, 近藤 寿氏をはじ め, 多くの学生に手伝って頂きました。 また本論文は東 京工業大学の翠川三郎氏, 査読委員である座間信作氏,

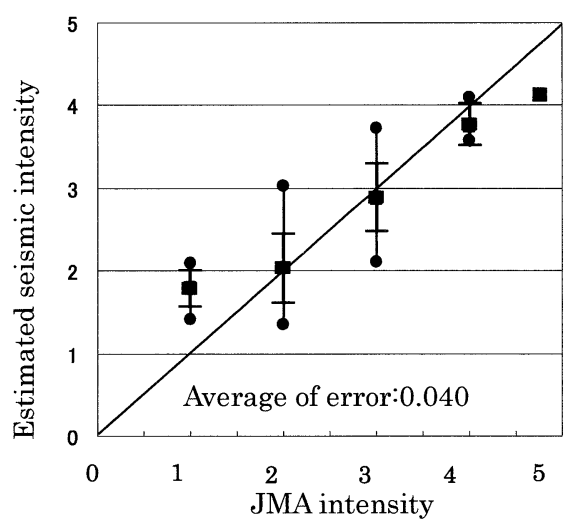

(b) The estimation by the strong ground motion records

Fig. 15. The comparisons of seismic intensities between the observations by JMA and the estimations by this study, for the 2000 Northeastern Chiba Earthquake. The rectangular marks, the horizontal bars, and the solid circles are the averages, the standard deviations, and the minimum/ maximum values of the estimations, respectively.

杮下 毅氏，および，編集担当である高橋道夫氏による ご指摘・ご議論により大きく改善されました，本研究は 防災科学技術研究所之の共同研究「地震素過程之地球内 部構造の解明に関する総合研究（平成 $10 \sim 12$ 年度)」, および「強震動・震災被害予測システムに関する研究 (平成 13 年度) 」, 大成建設との共同研究「GIS を用いた 地震被害予測システムの構築 (平成 11 年度)」, 文部科 学省による「大都市大震災軽減化特別プロジェクト」, 科 学技術振興事業団・計算科学技術活用型特定研究開発推 進事業による「地震災害予測のための大都市圏強震動シ ミュレータの開発 (平成 13 年度)」, および, 学術フロン ティア事業である「工学院大学地震防災・環境研究セン ター」による研究助成によって行われました. 地形分類 図のデジタル化に際し, 日本地図センターによる土地分 類図を使用させて頂きました。また，強震記録として K-NETのデー夕を使用させて頂きました，記して感謝 させて頂きます. 


\section{文献}

防災科学技術研究所, 1998, Freesia による地震のメカ ニズム情報 (8/28 東京湾の地震), http://argent.geo. bosai.go.jp/freesia/event/tdmt/19980828234500/ update1/index-j.html.

防災科学技術研究所, 2000, Freesia による地震のメ力 ニズム情報 (6/3 千葉県北東部), http://argent.geo. bosai.go.jp/freesia/event/tdmt/20000603085300/ update $2 /$ index-j.html.

防災科学技術研究所, 2002, 地震情報伝達システム ROSE, http://www.hinet.bosai.go.jp/rose/index. htm.

伊藤茂郎・川瀬 博, 2001, 統計的グリーン関数法によ る強震動予測法の検証と仮想福岡地震への適用, 日本 建築学会構造系論文報告集, 540, 57-64.

石田瑞穂・大井昌弘, 2002, 地震情報伝達システム ROSE の開発, 日本建築学会大会・災害部門パネル ディスカッション,「インフォメーションテクノロ ジーと地震防災」資料集.

加藤研一，2001，K-NET 強震記録に基づく 1997 年鹿 児島県北東部地震群の震源 - 伝播経路 - 地盤増幅特性 評価, 日本建築学会構造系論文報告集，543，61-68.

気象庁, 1996, 震度の算出方法, 震度を知る一基礎知識 とその応用一。

桐山孝睛, 2000, 国におけるリアルタイム地震防災シス テムのあり方, 第 2 回リアルタイム地震防災シンポジ ウム論文集一リアルタイム地震防災の近未来の姿を探 る一, 107-112.

国土庁土地局国土調査課, 1976, 土地分類図 13（東京 都) $(1 / 10$ 万), (財) 日本地図センター.

国土地理院, 1997, 数值地図 $250 \mathrm{~m}$ メッシュ (標高), 財団法人日本地図センター.

福和伸夫・荒川政知・小出栄治・石田栄介, 1999, GIS を用いた既存地盤資料を活用した都市域の動的地盤モ デル構築，日本建築学会技術報告集，9,249-254.

松岡昌志・翠川三郎，1994，国土数值情報とサイスミッ クマイクロゾーニング, 第 22 回地盤震動シンポジゥ ム, 日本建築学会, 23-34.

翠川三郎, 1996, 最近の強震計ネットワークについて一 阪神大震災以降の動向一, 建築防災, 12 月号, pp. 12-16.

翠川三郎・松岡昌志, 1995 , 国土数值情報を利用した地 震ハザードの総合的評価, 物理探査, 48, 519-529.

Midorikawa, S., M. Matsuoka, and K. Sakugawa, 1994, Site effects on strong-motion records observed during the 1987 Chiba-ken-toho-oki, Japan earthquake, Proceeding of ninth Japan Earthquake Engineering Symposium, 3, 85-90.

Midorikawa, S. and S. Abe, 2000, Real-time assessment of earthquake disaster in Yokohama based on dense strong-motion network, 12WCEE, 1036.

翠川三郎, 2002, リアルタイム地震防災システムの現状
と利用例, 日本建築学会大会・災害部門パネルディス カッション,「インフォメーションテクノロジーと地 震防災」資料集.

内閣府, 1999, 内閣府地震被害想定支援ツール (1999 改 訂版）http://www.bousai.go.jp/manual/tool/tool_ index.html.

内閣府, 2001, 内閣府地震被害想定支援マニュアル (2001 改訂版) http://www.bousai.go.jp/manual/ manual.html.

日本地図センター, 1992, 数值地図情報 KS-156-1

大井昌弘, 2001, 地震情報伝達システム (ROSE), 強震観

測ネットワークに関するシンポジゥム 21 世紀の強 震観測ネットワークとそのデータ流通をデザインする 一鳥取県西部地震・芸予地震の経験を踏まえて一，日 本地震学会主催, 21-24.

大西淳一・山崎文雄・若松加寿江, 1999, 気象庁地震記 録の距離減衰式に基づく地点増幅特性と地形分類の関 係，土木学会論文集，626, I-48, 79-91.

司 宏俊・翠川三郎, 1999, 断層夕イプおよび地盤条件 を考慮した最大加速度・最大速度の距離減衰式, 日本 建築学会構造系論文報告集, 523, 63-70.

清水善久・小金丸健一・中山 渉・山崎文雄, 2002, 超 高密度地震防災システム (SUPREME) の開発, 国土セ イフティネットシンポジゥム一広域リアルタイム地震 ネット構築へ向けて一，17-20.

東京大学地震研究所, 1996, EIC 地震学ノート No. 2, Sep. 11, '96 http://wwweic.eri.u-tokyo.ac.jp/EIC/ EIC_News/960911.html.

損害保険料率算定会, 1998 , 地震被害想定資料集

横田 崇, 2002, 気象庁におけるナウキャスト地震情報 への取り組み，国土セイフティネットシンポジゥム— 広域りアルタイム地震ネット構築へ向けて一，37-47. 若松加寿江・松岡昌志・久保純子・長谷川浩一・杉浦正 美，2002, 全国地形・地盤ディジタルマップの構築と K-NET, KiK-net 観測点の微地形特性，第 11 回日本 地震工学シンポジゥム, CD-ROM.

Wald D. J., V. Quitoriano, T. H. Heaton, H. Kanamori, and C. W. Scrivner, 1998, Trinet "ShakeMaps": Rapid generation of peak ground motion and intensity maps for earthquakes in Southern California, SMIP98 Proceedings, Oakland.

座間信作・細川直史, 1996, 簡易型地震被害想定システ 么の開発, 消防研究所報告, 82, 26-33.

座間信作・遠藤 真・細川直史・畑山 健, 2000, 簡易 型地震被害想定システムの改良, 消防研究所報告, 90 , $1-10$.

地震予知総合研究振興会, 1998, 地震加速度情報の検索 ページ, http://www.adep.or.jp/shindo/Screen / C9197.html.

地震予知総合研究振興会, 2000, 地震加速度情報の検索 ページ, http://www.adep.or.jp/shindo/Screen / C20526.html. 